the earliest proof of a common translation in space was given by the same observer from the Madras observations I853-58, which formed a part of vol. xxviii. of the Memoirs of the Royal Astronomical Society. Not having seen any distinct reference to the very large and uniform motions of these stars in astronomical treatises, we adverted to them in NATURE as above.

Again, the common proper motions of Regulus and Lalande 19749 , mentioned by $M$. Flammarion in the same communication have been long remarked. The same may be said in the case of 9 and 1o Ursæ Majoris, one of the systems to which he refers in a paper presented to the Academy on November I2. Any one who has carefully utilised the very valuable fourteenth volume of the Dorpat observations must have been familiar with this case, and, we may add many similar ones, though the proper motions involved may be to smaller amount. This volume contains Mädler's laborious work upon 3222 of Bradley's stars, of which he gives positions reduced to 1850 , and where all the catalogues available at the time and considered deserving of confidence were brought to bear. Not the least important feature in this work is the addition of two columns, not usually found in catalogues, containing the amount of secular proper motion in arc of great circle $(r)$ and the angular direction of this motion $(\phi)$ counted from north round by east to $360^{\circ}$. On p. 155 we have-.-

$$
\begin{aligned}
& \text { For } 9 \text { เ Ursæ Majoris } \ldots \quad r=52^{\prime \prime} \cdot 5 \quad \ldots \quad \phi=238^{\circ} \cdot 9 \\
& \text { "10 }, " \quad \ldots r=52^{\prime \prime} \cdot 6 \quad \ldots \quad \phi=238^{\circ} \cdot 5
\end{aligned}
$$

But, as we have stated, other similar cases are readily detected by an inspection of these columns. For instance : in $\gamma$ and 58 Tauri, distant $35^{\prime}$, where $r=13^{\prime \prime}$, $\phi=97^{\circ} ;$ in 66 and 68 Draconis, clistant $43^{\prime}, r=13^{\prime \prime} \cdot 5$, $\phi$ about $69^{\circ}$ and for wider stars, in 26 and 34 Pegasi, dis$\operatorname{tant} 4^{\circ} 25^{\prime}$, where $r=30^{\prime \prime}, \phi=84^{\circ}$; in $\eta$ and Io Arietis, distant $5^{\circ} \mathrm{II}^{\prime}, r=\mathrm{I} 5^{\prime \prime} \cdot 5, \phi=86^{\circ}$, with other neighbouring stars, moving in nearly the same direction, and again in $\mu$ and 54 Aquilæ, distant $5^{\circ} 13^{\prime}, r=27^{\prime \prime}, \phi=121^{\circ}$. The list might be largely increased.

It is nevertheless to be expected that the researches which M. Flammarion is so industriously following up with respect to stellar systems may lead to a considerable addition to our knowledge of them, in cases which are not thus easily discovered from existing catalogies, particularly by determining the proper motions of stars, not yet submitted to such investigation.

The Minor Planets.-A letter from Prof. Watson, of Ann Arbor, U.S., to M. Yvon Villarceau, dated November 5 , deranges the ordinal numbers of the small planets given in this column last week, from No. 175 onwards. It appears that on October I he discovered a planet Iom., which he duly notified by telegraph to the Smithsonian Institution, but by some unexplained circumstance the information was not transmitted by cable to the Observatory of Paris, as usual with such discoveries. Supposing this object to be really a new planet, it will be No. 175 , and the subsequent discoveries mentioned last week will be on the same supposition, advanced a unit. Elements of No. 172 appear in Astron. Nach., No. 2,176, and of No. 176 in the Paris Bulletin International of November 25.

THE CORDOBA OBSERVATORY.-Within the last few days, Mr. John M. Thome, the zealous co-operator with Dr. B. A. Gould in the important astronomical work carried on for several years past at the Observatory of the Argentine Republic, has visited this country on his return to Cordoba from the United States. We have seen in his hands proofs of the charts of the Argentine "Uranometria," which are on a much larger scale than those of Argelander, Heis, and Behrmann. They have been engraved in New York. This work is expected to be soon published; also large lunar photographs taken at Cordoba. All the stars in the "Uranometria" have been meridionally observed.

\section{CARL VON LITTROW}

CARL LUDWIG VON LITTROW, whose death has been announced during the past week, was born at Kasan on July I8, I 8I I. His father, Joseph Johann von Littrow, the eminent astronomer, afterwards Director of the Imperial Observatory at Vienna, was at that time Professor of Astronomy in the University of Kasan, where he founded an observatory. The son was educated under the father's direction, and in $183 \mathrm{I}$ was appointed assistant at the Observatory at Vienna, of which institution the elder Littrow had taken the superintendence in 1819 , removing thence from Ofen. In 1835 he first appeared as an astronomical writer, having in that year published an account of Hell's Journey to Wardoe and of his Observations of the Transit of Venus in 1769 at that place, from the original day-boolss; also a History of the Discovery of General Gravitation, by Newton, and Treatises upon Comets, more especially on Halley's, which was then appearing. In 1839 he published at Stutgard a Celestial Atlas, and a work which in the Catalogue of the Pulkova Library is called a Translation of Airy's "Populäre physische Astronomie," by which is most probably intended the well-known Treatise on Gravitation published by the Astronomer-Royal in I834, though elsewhere Littrow's work is stated to refer to the history of Astronomy during the early part of the nineteenth century, presented to the British Association in 1832 .

In 1842 Carl von Littrow succeeded his father as Director of the Observatory of Vienna, and the establishment has continued in vigorous activity under his charge. He has principally devoted the energies of the Observatory to equatorial astronomy, following up with diligence the observations of comets and planets, and with the aid of able assistants determining their orbits. Some of the most complete cometary discussions have emanated from the Observatory of Vienna while under his charge. The Annalen der Sternwarte in Wien, have been continued, and valuable astronomical wor: is contained in them, as for instance in the first volume of the third series, which appeared in $185 \mathrm{I}$, where we have the positions of the stars in Argeland r's Northern Zones reduced by Oeltzen to $\mathrm{I} 842$, the epoch for which elements of reduction were given in the Bonn volume. Littrow was a frequent contributor to the publications of the Vienna Academy. In one of his memoirs-"Bahnähen $z$ wische: den periodischen gestirnen des Sonnensystem :" printed in the Sitzungsberichte of the Academy fur January, 1854 he applied an orizial proctss of westigat on of the points of nearest amproct amongt the orbits of the smiall planets discovered up to that tune, and the orbits of the periodical coriets-d troublesome work in which me hanicil aid was introduce ; the resul was the discovery of many close approximations of planets wht? planets, planets with com:ts, and of comets with comers amongst the latter near approaches of Bela's contat t:? the orbit of Halley's in $35^{\circ}$ and $198^{\circ}$ h.liocentric longutude. When interest was excied relative to the expected return of the comet of 1556 , wh ch at that period was supposed to have been previous y observed in 1264 , Littrow was the means of bringing to light an unknown treatise by Heller, which, with the chart of Fabricius, has allowed of a much improved determination of the orbit, and similarly he made known interesting particulars with reference to the remarkable observation by Steinheibel and Stark of a rapidly-moving black spot upon the sun's disc on February 12, 1820. Littrow was a constant con tributor to the columns of the Astronomische Nachrichten. The names of Hornstein, Oeltzen, Weiss, Schulh of, and others are well known in connection with the work of the Vienna Observatory during Littrow's direction. His death occurred on the 16 th inst.

Von Littrow's wife, Aliguste Littrow-Bischoff, is one of the best known Austrian authoresses of the present time. The genial qualities of the astronomer and his wife made 
them the centre of a large and admiring circle, and their residence was one of the most favourite gathering-places of the literary and scientific celebrities of Vienna.

\section{$B A C T E R I A^{1}$}

I $N$ a short paper communicated to the Royal Society at 1 the close of last session, Prof. Tyndall did me the honour to criticise certain words reported to have been used by me at a meeting of the Association of Medical Officers of Health in January last. Although I am much indebted to him for the opportunity he has thus afforded me of discussing an important subject- before this Society, I cannot refrain from expressing my regret that he should have thought it desirable to quote at length, and thus to place on permanent record in the Society's Proceedings, the expressions used on the occasion above mentioned. I regret this because these expressions occur in an abbreviated and incomplete abstract of a hastily prepared discourse not intended for publication.

As, however, I am well aware that Prof. Tyndall's purpose in his communication was not to criticise the language, but the erroneous views which the language appeared to him to contain, I shall make no further reference to the quotation; but shall regard it as the purpose of the present paper, first to reply to the reasoning embodied in his last communication, and secondly to corroborate certain statements previously made by me, to which he has taken exception in the more extended memoir published in the I66th volume of the Philosophical Transactions.

It will be my first object to enable the Fellows of the Royal Society to judge how far the views I entertain differ from those which have been enunciated here and elsewhere by Prof. Tyndall. Biologists are much indebted to him for the new and accurately observed facts with which he has enlarged the basis of our knowledge, as well as for the admirable methods of research with which he has made us acquainted. As regards the general bearing of these facts on the doctrine of Abiogenesis, I imagine that we are entirely agreed. So far as I can make out, the difference between us relates chiefly to two subjects, namely, the sense in which I have employed the words "germ" and "structure," and the extent of the knowledge at present possessed by physiologists as to the structure and attributes of the germinal particles of Bacteria.

Although Dr. 'Tyndall, in the title of his paper, refers to my "views of ferment," yet as he makes no further allusion to them, I will content myself with stating that in the passage quoted, the first sentence (from the words "In defining" to the word "living") has nothing to do with the following sentences, having been placed in the position which it occupies in the quotation by the abstractor. The paragraph ought to begin with the words "Ten years ago."

Of the meaning which attached itself to the word "germ" in the days of Panspermism a correct idea may be formed from the following passage from M. Pasteur's well-known memoir "Sur les Corps organisés qui existent dans l'Atmosphère." "There exist," says he, "in the air a variable number of corpuscles, of which the form and structure indicate that they are organised. Their dimensions increase from extremely small diameters ${ }^{2}$ to onehundredth of a millim., I' 5 hundredth of a millim., or even more. Some are spherical, others ovoid. They have more or less marked contours. Many are translucent, but others are opaque, with granulations in their interior. .... I do not think it possible to affirm of one of these corpuscles that it is a spore, still less that it is the spore of a particular species of microphyte, or of another, that it is an egg or the egg of a particular microzoon. I confine myself to the declaration that the corpuscles are

I "Remasks on the Attributes of the Germinal Particles of Bacteria, in reply to Prof. Tyndall," by. J. Burdon-Sanderson, M.D., LL,D., F.R.S. Paper read at the Royal Society, November 22 , evidently organised ; that they resemble in every respect the germs of the lower organisms, and differ from each other so much in volume and structure that they unquestionably belong to very numerous species." Such are the "germs" of M. Pasteur, and such is the conception of a germ which was entertained by informed persons up to 1870 , and is very generally entertained up to the present moment.' It is obvious that these "corpuscules organisés" were, if they had any relation to Bacteria, not bacterium germs in Dr. Tyndall's sense, but "finished organisms," and yet it was of these that M. Pasteur said that it was "mathematically proved" that they were the originators of the organisms which are developed in albuminous liquids containing sugar, when exposed to the atmosphere.

With reference to the word "structure" I would point out that in the passage quoted from my lecture it is distinctly stated that the bacterial germ is endowed with structure in the molecular sense, but not in the anatomical sense. The meaning of the expression "anatomical structure" was, naturally, not defined, considering that the persons whom I was arddressing might be supposed to be familiar with it. As, however, my failing to do so has apparently led to some uncertainty as to my meaning, I must, to avoid future misunderstandings, define more completely the difference between the two senses in which the word was used by me.

The anatomical sense of the word structure may be illustrated by referring to its synonyms, to the English

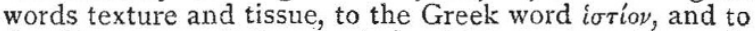
the German word Gewebe, from which two last the words in common use to designate the science of structure, viz., histology and Gewebelehre are made up. What I have asserted of the germinal particles of Bacteria is, that no evidence exists of their being endowed with that particular texture which forms the subject of the science of histology. In biological language there is a close relation between the words structure and organization, the one being an anatomical, the other a physiological term ; either of these words signifies that an object to which it is applied consists of parts or structural elements, each of which is, or may be, an object of observation. As the observation is unaided or aided, the structure is said to be macroscopical for microscopical. The biologist cannot recognise ultra-microscopical structure or organisation except as matter of inference from observation, i.e., from observing either that other organisms, which there is reason to regard as similar to the object in respect of which structure is inferred, actually possess visible structure, or that the object can be seen to possess structure at a later period of its existence. As instances in which the existence of structure is inferred the following may be mentioned:-The protoplasm of a Rhizopod is admitted to have structure because, although none can be seen in the protoplasm itself, the complicated form of the calcareous shell which the protoplasm makes or models can be seen. By analogy therefore other organisms which are allied to the Rhizo. pod are inferred to have structure, and from these, or from similar cases, the inference is extended to all kinds of cells, with respect to which it is taught by physiologists that although, in certain cases, no parts can be distin. guished, the living material of which they consist is nevertheless endowed with structure or organisation. Similarly, we assume, that a Bacterium possesses a more complicated structure than we can actually observe, because in other organisms which are allied with it by form and life history, such complications can be seen. Again, in all embryonal organs we admit the existence of structure before it can be seen, because in the course of

I Before $I$ became aware that the contaminating particles of water are ultra-microscopical I myself was engaged earnestly in hunting for germ both in water and air. The search has been continued by others up to much later period. Those who desire information on the organised particles of the atmosphere will find the subject exhaustively treated by Dr. Douglas Cunningham in a report entitled "Microscopical Examinations of Air," lately issued by H.M. Indian Government. 